\title{
“YOU ARE NOT ALLOWED TO PULL SOMEONE'S TAIL!" A CROSS-CULTURAL COMPARISON OF SOCIO-MORAL COMMENTS IN ESTONIAN AND SWEDISH PEER INTERACTION $^{1}$
}

\author{
Boel De Geer and Tiia Tulviste
}

\begin{abstract}
The study compared the spontaneous use of verbal comments on socio-moral behavior in 20 Estonian and 22 Swedish kindergarten peer dyads during free play situations. All comments on Moral and Socialconventional rules were coded according to Piotrowski's (1997) model, as well as according to outcomes (agreement, rejection, negotiation or silence). We found that Swedish children were more active in making socio-moral comments than the Estonian children, by commenting more on rules of Rights, Harm to others and Miscellaneous conventional rules. Both the Estonian and the Swedish children made more comments referring to social-conventional than to moral rules. As to outcomes, agreement was the most frequent type in the Swedish data, whereas silence dominated in the Estonian group. Also, the Estonian children rejected both moral and social-conventional rules more often than the Swedish children. Previous research in family dinner conversations in Estonia and Sweden has suggested a more egalitarian interaction pattern in the Swedish homes as well as daycare institutions and schools than in the Estonian equivalents (De Geer et al. 2002; Tulviste et al. 2002). A high amount of comments on socio-moral behavior, particularly comments on rights and harm to others, can be claimed to a further support for this claim.
\end{abstract}

Keywords: Peer discourse; Pragmatic socialization; Cross-cultural comparison; Socio-moral behavior; Moral rules

\section{Introduction}

The present study focuses on the use of verbal comments on socio-moral behavior in Estonian and Swedish kindergarten peer dyads during free play situations. Socio-moral rules are rules of social interaction and are conveyed in social interaction, both inside and outside the home. In the integrated process of language acquisition and socialization of children (Ochs 1996) language is used as one tool in conveying the socio-moral rules of a specific society. The linguistic tools used in linguistic socialization are often referred to as metapragmatic comments (Becker 1990; Blum-Kulka 1990) and are used

${ }^{1}$ Research for this article was supported by a grant from the Baltic Foundation in Sweden (No. 3000902). We thank Dr. Luule Mizera for helping to gather and transcribe the Estonian data. 
in order to point out either lack of adherence to a norm, e.g. turn-taking rules, politeness phrases etc. Comments can also be used as explicit directives to encourage proper or desired behavior. Comments may explicitly point at both verbal and non-verbal behavior in the distant past, the immediate past or in the near or distant future and are used with the explicit or implicit aim to make someone behave or speak or act in a certain way, i.e. to teach, or draw attention to, conversational or socio-cultural norms which are known to vary between different cultures (e.g., Tannen 1981; Blum-Kulka 1990, 1997; Blum-Kulka \& Sheffer 1993). Socio-moral rules have in several studies been divided into two kinds (Turiel 1983; Tisak \& Turiel 1984; Piotrowski 1997): Moral and social-convention. Moral rules concern questions of justice, fairness, rights, kindness etc., whereas social-conventional rules have to do with arbitrary agreed-on constructions like game rules, tidiness, and issues of what is regarded as proper behavior in a certain situation.

There exists a wide range of research into how young children acquire and develop rules of morality and social-conventional rules (e.g.; Haste 1987, Miller \& Goodnow 1995). These studies mainly concern young children's acquisition or negotiation of moral and social-conventional rules and how this is performed in naturalistic home settings with parents - usually only mothers - and/or siblings (Dunn and Munn 1987; Smetana 1989; Miller \& Goodnow 1995; Piotrowski 1997; Rogoff 1990). The results of these studies suggest that mothers pay their attention to conventional rules more often, whereas siblings focus more on moral rules (Piotrowski 1997; Smetana 1993). Other studies are made in preschool or daycare settings and consider either naturalistic interaction or experimental studies (Smetana \& Breages 1990; Smetana, Schlagman \& Walsh Adams 1993). Adults and older children use language in order to convey norms and rules governing socio-cultural behavior. This conveyance can be direct or indirect, explicit or implicit, and may appear in the form of direct instructions or commands of how to behave or in the use of language or behavior, to construct examples of linguistic and socio-cultural behavior. Adults' language and behavior constitute important means of socialization, in the form of guided participation (Rogoff 1990). Home interaction, often around the dinner table, provides families with an opportunity of joint conversation on a regular basis where children can learn, be taught, and make inferences about the norms and rules governing linguistic and social behavior. It is one of few regular time frames for intergenerational gathering (Ochs \& Taylor 1992a; Blum-Kulka 1997) and family interaction in general constitutes a forum for children to make their earliest social experiences, e.g. moral and social-conventional discussions. Piotrowski (1997), in her study of young children (aged 2-4 years) and their older siblings (aged 4-11 years), found that sibling relationships provide an increasingly important forum for socio-moral socialization.

Peer interaction constitutes an opportunity for children to, without adults' or older children's guidance or supervision, test their developing norm systems and indeed, when they do it offers an opportunity for us to study their growing knowledge.

Consider the following example (1) where two Swedish girls, Elsa aged 4;11 and Lisa 4;5, are playing in the home corner, cutting a toy pizza. The excerpt offers several examples (in bold) of comments on socio-moral behavior. 
(1) “Cutting the pizza” - Swedish girls' dyad.

$\begin{array}{lll}\text { 1 Elsa: } & \text { jag kan skära. } & \text { I want to cut. } \\ \text { 2 Lisa: } & \text { inte skära än. } & \text { not cut yet. } \\ \text { 3 Elsa: } & \text { jag får skära en och du får skära } \text { en. I can cut one and you can cut one. } \\ \text { 4 Lisa: } & \text { xxx. } & \\ \text { 5 Elsa: } & \text { vi får skära en var. } & \text { we can cut one each. } \\ \text { 6 Lisa: } & \text { vi sätter undan den här } & \text { we put this one away. } \\ \text { 7 Elsa: } & \text { två var ska vi skära. } & \text { two each we will cut. } \\ \text { 8 Lisa: } & \text { nej jag vill ha den. } & \text { no, I want that one. } \\ \text { 9 Elsa: } & \text { jag vill göra först/ det är jag först. I want to do first/ it’s me first. } \\ \text { 10 Lisa: } & \text { jag tog det. } & \text { I took it. } \\ \text { 11 Elsa: } & \text { du får ta och skära två. } & \text { you can cut two. } \\ \text { 12 Lisa: } & \text { två. } & \text { two. } \\ \text { 13 Elsa: } & \text { två stycken. } & \text { two pieces. } \\ \text { 14 Lisa: } & \text { ska jag skära två stycken? } & \text { shall I cut two pieces? } \\ \text { 15 } & \text { ska jag skära så? } & \text { should I cut like this? } \\ 16 \text { Elsa: } & \text { skär så och sen ska vi skära så. } & \text { cut like this and then we cut like that. } \\ \text { 17 Lisa: } & \text { så så+/jag skär så och så. } & \text { so, so/ I cut like this and like that. } \\ 18 \text { Elsa: } & \text { du ska inte skära alla. } & \text { you shouldn’t cut all of them. } \\ 19 & \text { du är inget snäll. } & \text { you are not kind. } \\ 20 & \text { xxx. } & \\ 21 \text { Lisa: } & \text { men så gör man. } & \text { but that’s the way you do it. } \\ 22 \text { Elsa: } & \text { jag vill också. } & \text { I want too. } \\ 23 & \text { de det var min kniv. } & \text { it was my knife. }\end{array}$

In the above example several socio-moral issues are raised, for instance positive justice (line 3, 5, 7), rights (line 9, 22), negative justice (line 18), and unkindness (line 19). The two girls are regulating each others moral behavior.

Previous studies on Estonian and Swedish family dinnertime interaction (De Geer Tulviste, Mizera \& Tryggvason 2002), found that Swedish families made more comments on moral transgressions than Estonian families (39\% of all comments, compared to 9\%). These comments regarded issues of fairness, justice, harm, teasing, adherence to rules, etc. A further study on the same Swedish data, focusing on different types of socio-moral comments (De Geer 2004), revealed that Swedish mothers provided more than $50 \%$ of all comments, compared to fathers and adolescents. The parents' comments were mainly aimed at children, whereas children's comments more often were aimed at people not present at the table. The Swedes have been characterized as avoiding getting into conflicts (see e.g. Daun 1991), at least, we would like to add, when it comes to more serious questions. Also, both mothers and fathers more often commented on the social-conventional rather than on the moral behavior of their children, a fact also pointed out by Piotrowski (1997). The children, however, commented on moral and social-conventional behavior to the same degree. Comments directed towards people present at the table mainly concerned social-conventional rules, whereas comments on others' behavior more often regarded moral rules.

Concerning outcomes, i.e. the reaction following a comment, it is possible to separate two distinct types: Compliance or non-compliance (Kuczynski et al. 1987; Kuczynski \& Kochanska 1990). Particularly non-compliance can appear in different shapes - as passive non-compliance (ignoring, silence) or active non-compliance (resistance, negotiation). In several previous studies on regulation (De Geer \& Tulviste 2002; De Geer, Tulviste \& Mizera 2005), on competition vs. cooperation (De Geer, Tulviste \& Tryggvason 2004), and to some extent in outcomes of comments on verbal 
and non-verbal behavior (De Geer et al. 2002), Swedish groups have been significantly outstanding when it comes to negotiation, compared to Estonian groups. On the other hand, Estonian groups have been found to meet comments as well as regulation with silence to a much higher degree than Swedish groups.

Society in Sweden has changed dramatically during the $20^{\text {th }}$ century. From being a poor, rural country, dominated by the power of the Lutheran church, Sweden has developed into a modern welfare state under the leadership of the social democratic party. From authorities the importance of creating a "modern" citizen, leaving old habits and traditions behind has been stressed. In spite of this, although secularization has proceeded far, people are still influenced by the older ways of thinking (Skogar 2000). In a society where moral and social rules are being less stressed by "authorities" like state, church and school, it seems likely that people become more preoccupied with this kind of rules. According to Löfgren (1993) there are "many written but far more unwritten rules about how to be a good - and modern - Swede" (1993: 235). Many of these rules stem from the de- and re-collectivization processes that took part during the $20^{\text {th }}$ century, replacing traditional collective loyalties and identities with new and modern ones. Eriksen (1993) describes a similar development in Norway and has suggested the notion "egalitarian individualism” to characterize the modern democratic ideology seen in the Norwegian society. The strong focus on comments on moral and social behavior in the Swedish families could therefore be the result of society's hidden, but taken-for-granted rules. In addition, in a study of narrative and explanatory language in Norwegian and American families, Aukrust \& Snow (1998) found Norwegian families to be very focused on social norms and deviations from these. Their results are well in line with ours, considering that the Swedish and the Norwegian societies are quite similar.

Estonia used to be a rural and Lutheran country like Sweden. However, in the middle of the $20^{\text {th }}$ century, when the democratization process was intensified in Sweden, in Estonia and the other Baltic states the civil society was governed and oppressed by the Soviet Union (1944-1991). Thus, today's Estonian parents had their upbringing in an authoritative society, with strict social norms and serious risks involved for those who did not conform. Their parents, in turn, belonged to a generation, which was deprived of their democratic rights and their possibilities of owning for instance private property. By contrast, today's Swedish parents are the children of the generation who built the Swedish democratic society and as children they were told about the importance of democracy and equality. It is not unlikely that such a historic background may have an influence on people's conception of socio-moral matters. We have previously found that questions concerning proper social behavior are often raised in Swedish but not in Estonian family context (De Geer et al. 2002) and the aim of the present study is to investigate preschool children's use of comments on socio-moral behavior, since not only family context, but also institutional settings, provides children with experiences and possibilities of social conflicts and discussions (Smetana 1989).

\section{The present study}

Children's acquisition and development of socio-moral rules can be studied in many ways - through experiments, structured play, interviews etc. Our study focuses on the use of spontaneous verbal comments on socio-moral behavior during free play in 
kindergarten peer dyads of same and mixed sexes. Our aims are to investigate the following:

\section{Amount of socio-moral comments}

To what extent are the children referring to socio-moral rules? Are there any differences between the two groups of children? Following our previous findings, we would expect the Swedish group to be more concerned with socio-moral rules and thus make more comments on this kind of behavior.

\section{Type of behavior commented on}

Are any of the two types of rules - moral and social-conventional - referred to more than the other? Haste (1987) found that preschool children made very few comments on each other's social-conventional behavior, but rather to moral transgressions. On the other hand, in our previous study on Swedish family dinnertime conversation (De Geer 2004), the pre-adolescent children commented on moral and social-conventional behavior to the same degree. Depending on whether the commenting behavior is a matter of age or/and development rather than culture, it might therefore be likely to expect the same kind of distribution between moral and social-conventional rules at least from the Swedish peers.

\section{Gender differences}

Are there any gender differences in the use of comments on socio-moral behavior? Previous researchers have not found any significant gender differences in the frequency of using moral and conventional rules in peer talk. The exception is the study by Tulviste and Koor (2005), reporting gender differences with respect to social rules when a girl or a boy is playing with gender-typical toys (girls with dolls or boys with trucks). Namely, boys referred to moral rules more often than girls did.

\section{Outcome of socio-moral comments}

In De Geer (2004), negotiation was the by far most frequent outcome of a comment on social-conventional behavior, closely followed by agreement. Furthermore, comments on social-conventional behavior appeared to be more negotiable than moral rules, as children more often questioned them. Similar findings were made by Smetana, Crean and Campione-Barr (2005). It would therefore seem logical to expect a higher amount of negotiation from the Swedish peers than from the Estonian, and also a more negotiation of social-conventional rules than of moral rules. Also, based on previous findings in Estonian groups, we would expect the Estonian children to meet comments on socio-moral behavior with silence more often than the Swedish children.

\subsection{Data collection}

42 dyads were included in the study: 20 Estonian (Tallinn and Tartu) and 22 Swedish dyads (Älvsjö, a southern, town-like suburb of Stockholm). All cities have both universities and major industries. Stockholm and Tallinn are capitals, whereas Tartu is not. The Stockholm suburb is, however, quite small and "small-townish", and Tallinn is indeed a very small capital. 
All children's families were monocultural, and monolingual speakers of Estonian or Swedish. All children came from middle to upper middle class homes, as defined by the parents' education and occupation. One very obvious reason for choosing this group was that it would enable us to continue the research tradition in these social and geographic areas started already in the 1990's. Letters asking parents for permission to video record the children in a play situation together with a freely chosen peer were distributed to kindergartens in the above areas. The kindergarten staff collected parents' permissions.

Table 1 presents descriptive data on dyads and recording time per group. Table 1. Descriptive statistics on dyads and recording time

\begin{tabular}{cll}
\hline & Estonian & Swedish \\
\hline Number of dyads & 20 & 22 \\
- Girls' dyads & 9 & 11 \\
- Boys' dyads & 11 & 6 \\
- Mixed dyads & - & 5 \\
Mean age (SD) & $5.36(0.58)$ & $5.13(0.54)$ \\
Mean recording time in minutes & 19.53 & 19.68 \\
\hline
\end{tabular}

The children were encouraged to choose a friend with whom they wanted to play. The Estonian children all played in same-gender dyads, but in five Swedish dyads the children preferred to play with a friend of the opposite sex. The recordings were made during the morning when the rest child group at the kindergarten was outdoors. The children were invited to play in a room and to use the toys available: Several small cars, a mat on the floor made as the map of a town, different types of construction material (Lego, Kapla, building blocks), a home set (stove, table, chairs, kitchen utensils), dolls and soft animals.

Prior to recordings, the researcher had spent time together with the children, participating in meals, play and other activities. One researcher only, in order not to disturb the children, performed the recordings. The researcher tried to keep an as "low profile" as possible, i.e. answered the children's' questions and helped them occasionally, but otherwise did not interact with them. The recordings were made with a very small digital video camera, positioned as far away from the children as possible. Without doubt, some children were more intimidated by the camera than others. On the whole, however, children of today are quite acquainted to video cameras and the majority seems not to mind very much about it.

\subsection{Method}

The video recordings were originally transcribed using the CHAT (Child Language Data Exchange System) transcription system (MacWhinney 1991). For readability reasons, all excerpts have been normalized into their present shape. 
All codings are based on utterances, according to work by Feilberg (1991), who defines an utterance as "a verbal unit, which has a terminal rising or falling tone unless the unit is interrupted".

All verbal comments on the perceived violations of social rules were identified and coded for its focus. All codings were made jointly in order to maintain a high interrater reliability. The social rules were analyzed according to the category system developed by Piotrowski (1997), who differs between moral rules and social conventional rules, and further differentiates moral rules into five, and social conventional rules into four subcategories. The coding conventions were originally designed by Piotrowski to characterize comments of what is considered preferable, desired or forbidden in mother-child and sibling-child relations.

The nine following types of social rules were identified:

Moral rules

Rights. Rules of possession and ownership.

Example: Varför har du tagit från min hög? [Why have you taken from my heap? Swedish girls dyad, when building with blocks]. Ära puudu minu kummutit! [Don't touch my commode! - Estonian girls dyad playing home].

Positive justice. Turns, sharing, and equity.

Example: Vi kan dela på dom för det finns rättså många. [We can share them because there are quite many of them. - Swedish mixed dyad playing with toy fish]. See on ebaaus et sinul kaks kappi on. [It is unfair that you have two cupboards. - Estonian girls dyad playing home].

Harm to others. Unkindness, teasing, or hitting.

Example: Du får inte dra ner brallerna. [You must not pull my trousers off. - Swedish boys dyad wrestling]. Ei tohi teha kiirabile niimoodi. Kiirabi surnud sees saab veel vigasemaks. [Your shouldn't do that to the ambulance. The dead people in the ambulance will get more crippled. - Estonian boys dyad playing with cars].

Past kindness/prosocial behavior. Previous acts of kindness and niceness.

Example: Jag ska säja dej en sak. Jag tycker om dej bara för du är så snäll och hjälper. [I tell you what. I like you because you are so kind and help me. - Swedish mixed dyad playing with cars].

General moral exhortations. No specific topic is mentioned, but a moral implication is present.

Example: Ät nu och gör ingenting annat! [Eat now and do nothing else! - Swedish girls dyad playing home].

\section{Social-conventional rules}

Rules of a game. Comments about a structured game.

Example: Man får bara åka på gatan. [You are only allowed to drive in the street. Swedish boys dyad playing with cars].

Destruction of property/tidiness of house. Comments concerning messes, cleanliness, tidiness, includes appropriate placement of objects. 
Example: Politsei maja lõhud ära! [You are breaking the police building. - Estonian boys dyad playing with cars]. Här var det en himla röra. [This is a terrible mess Swedish girls dyad playing home]. Mattan brukar ju faktiskt vara på golvet. Varför ligger den på spisen då? [The carpet usually lies on the floor. Then why is it on the stove? - Swedish girls dyad playing home].

General conventions. Comments concerning silly, funny, or odd behavior, requests or denial of permission, or appropriateness and correctness of a wide range of activities.

Example: Titta hur tokiga bilarna är! [Look how crazy the cars are! - Swedish girls dyad playing with cars]. Visst fick den lilla hästen bo här? För att hästen var så snäll mot dom? [Sure the little horse could live here? Because the horse was so kind to them? - Swedish mixed dyad playing with farm animals].

Miscellaneous conventions. Concern independence (doing things on one's own), gender-appropriate behavior, assignment of chores, proper use of money, reference to an authority figure, role- appropriate behavior, politeness, inappropriate language use etc.

Example: Det här är en pojke. Så den får vara piloten, visst? [This is a boy. So he can be the pilot, can't he? - Swedish mixed dyad playing with cars and planes].

\section{Outcome}

Piotrowski's (1997) study did not focus on outcome, i.e. the reaction following on a comment on moral or social-conventional behavior. We have chosen to include also outcome because we think this gives us valuable information about the children's internalization of rules as well as about more general interaction patterns. The outcomes were coded as follows:

Agreement. The addressee agrees, either verbally or non-verbally.

Example: Swedish girls’ dyad about children playing outdoors.

$\begin{array}{lll}\text { 1 Marie: } & \text { dom stör oss. } & \text { they are disturbing us. } \\ \text { 2 Jenny: } & \text { ja dom stör oss. } & \text { yes they are disturbing us. } \\ \text { 3 Marie: } & \text { jag kan nästan inte koncentrera mig nu. } & \text { I can hardly concentrate now. } \\ \text { 4 Jenny: } & \text { det kan inte jag heller. } & \text { neither can I. } \\ \text { 5 Marie: } & \text { fast jag måste försöka faktiskt. } & \text { but I really have to try. }\end{array}$

Rejection. The addressee rejects the comment.

Example: Estonian girls’ dyad.
1 Anna:
jouga ei saa midagi.
you can't get anywhere with force.
2 Rasma:
ma ei teinudki midagi jouga!
I didn't use any force! [insulted]

Negotiation. The addressee tries to negotiate the comment. See example (1) in the Introduction.

Silence. No clear reaction follows. 


\section{Results}

The number of comments on socio-moral rules in the Estonian dyads was 73, and in the Swedish dyads 204 . In both groups about $1 / 3$ of the comments concerned moral rules and 2/3 social-conventional rules (see Table 2 ).

Table 2. Number of utterances and comments, total and per child

\begin{tabular}{lllll}
\hline & \multicolumn{2}{l}{$\begin{array}{l}\text { Estonian } \\
\text { total }\end{array}$} & per child & \multicolumn{2}{l}{$\begin{array}{l}\text { Swedish } \\
\text { total }\end{array}$} & per child \\
& & & & \\
\hline Number of utterances & 4572 & 114 & 5234 & 119 \\
Number of comments & 73 & 1.83 & 204 & 4.63 \\
$\quad$ Moral rules & 18 & 0.45 & 52 & 1.18 \\
Conventional rules & 55 & 1.38 & 152 & 3.45 \\
\hline
\end{tabular}

Two-way ANOVAs were used to ascertain whether the dependent variable (types of social rules) varied as a function of Culture, and Child's Gender. To estimate differences between the means of using different types of rules by Estonian and Swedish children, post hoc comparisons with the LSD Test (planned comparison) were performed.

A two-way MANOVA for the rule types (moral vs. social conventional) revealed a significant effect of Culture (Estonia vs Sweden), Wilk's-Lambda $(2,75)=$ $0.91, \mathrm{p}<0.05$, but no effect of Child's gender (boys vs. girls), and no significant Culture $\mathrm{X}$ Gender interaction for the rule types used at $\mathrm{p}<.05$. One-way ANOVAs revealed a significant effect of Culture (Estonia vs Sweden) on the reference to moral rules, $F(1,78)=4.00, p<.05$, and on the reference to social-conventional rules, $F(1,78)=5,42$, $\mathrm{p}<.05$, due to the fact that Swedish children were likely to use more moral and socialconventional rules.

The foci of the comments are presented in Table 3 and Figure 1 and 2.

Table 3: Mean numbers of socio-moral comments

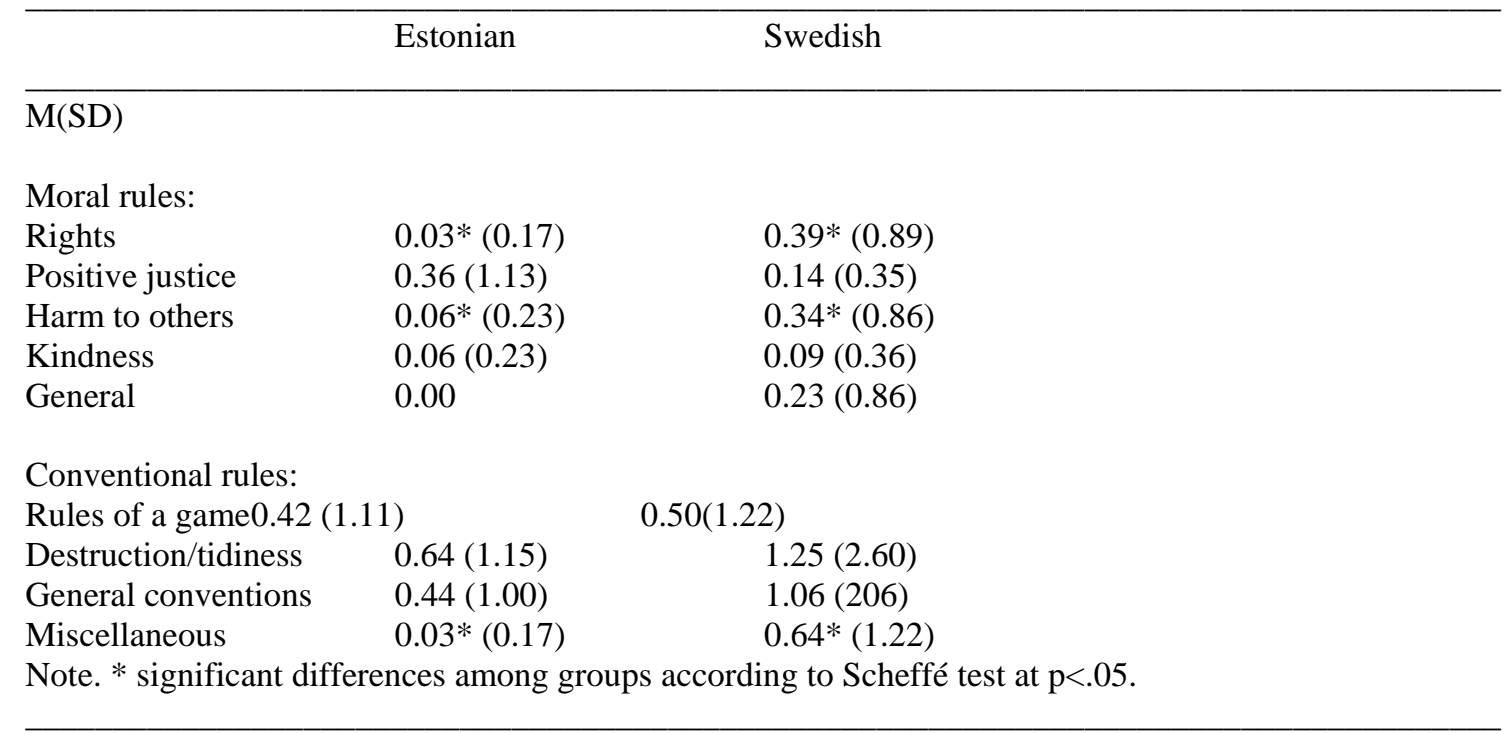


A two-way MANOVA for five types of moral rules indicated a trend of the effect of Country (Wilks' Lambda $(5,72)=.87, \mathrm{p}=.06)$, but no effect of Child's gender, and no Gender x Culture interaction.

One-way ANOVA showed that Swedish children made significantly more comments on Rights (including the rules of possession and ownership), $F(1,78)=5.61$, $\mathrm{p}<.05$.

(2) “A lot of fish” - Swedish mixed dyad playing with dinosaurs and fish.

$\begin{array}{lll}1 \text { Ulla: } & \text { här är en massa fiskar. } & \text { here was a lot of fish. } \\ 2 & \text { här är en massa fiskar. } & \text { here was a lot of fish. } \\ 3 & \text { massa massa massa fiskar. } & \text { lot lot lot of fish. } \\ \text { 4 Henrik: } & \text { ta upp+/ ta upp dom på bordet. } & \text { put up+/ put them up on the table. } \\ 5 \text { Ulla: } & \text { nej. } & \text { no. } \\ \text { 6. Henrik: } & \text { det här var mitt kött. } & \text { this was my meat. } \\ \text { 7 Ulla: } & \text { men Henrik jag vill ha! } & \text { but Henrik I want! } \\ 8 \text { Henrik: } & +<\text { xxx. } & \\ 9 & \text { jag har bara två. } & \text { I have only two. } \\ 10 & \text { jag har bara två. } & \text { I have only two. } \\ 11 & \text { i så fall snodde vi kött av varandra. } & \text { in that case we were snatching meat } \\ 12 & & \text { from each other. } \\ \text { 13 Ulla: } & \text { nej. } & \text { no } \\ \text { 14 Henrik: } & \text { joo. } & \text { yes } \\ \text { 15 Ulla: } & \text { men Henrik+/. } & \text { but Henrik+/ } \\ \text { 16 Henrik: } & \text { men jag har bara två. } & \text { but I have only two. }\end{array}$

The Swedish children had also a significantly higher amount of comments on Harm to others (including unkindness, teasing and hitting), $F(1,78)=3.72, \mathrm{p}<.05$.

(3) “Pulling someone’s tail” - Swedish girls dyad playing with jungle animals.

1 Mimmi:
2
3
4
5 Malin:

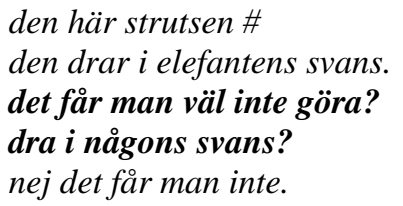

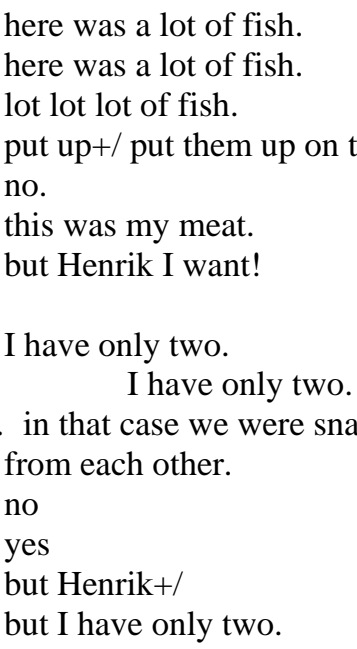

A two-way MANOVA for five types of social conventional rules indicated a main effect of Country (Wilks' Lambda $(4,73)=.88, \mathrm{p}<.05$ ), but no effect of Child's gender, and no Gender x Culture interaction.

A third category where the Swedish children produced significantly more comments than the Estonian children was Miscellaneous conventional rules, $\mathrm{F}(1,78)=8.78, \mathrm{p}<.01$. Example: Vad bra hon har mössa på det regnar idag. [Good that she is wearing a hat it's raining today. - Swedish girls dyad playing with dolls.].

(4) “The girl” - Swedish mixed dyad, playing with Lego.

$\begin{array}{llc}\text { 1 Greta: } & \text { visst får jag vara den här? } & \text { I can be this one, sure? } \\ 2 \text { Anders: } & \text { ja. } & \text { yes. } \\ \text { 3 Greta: } & \text { det är ju en tjej. } & \text { since it’s a girl. } \\ \text { 4 Anders } & \text { mm. } & \text { mm. }\end{array}$


Figure 1. Mean numbers of moral comments

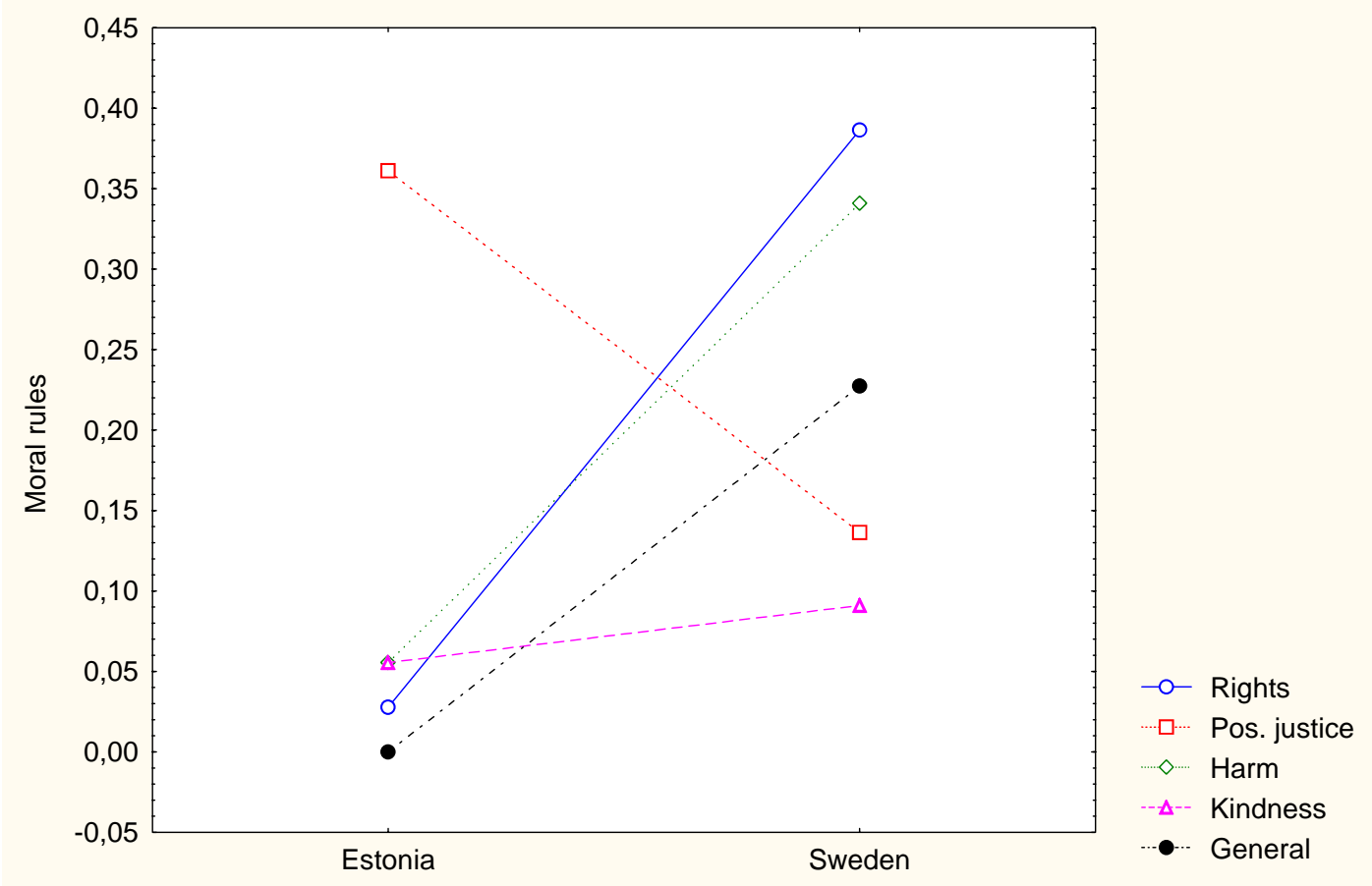

Figure 2. Mean numbers of Social-conventional comments

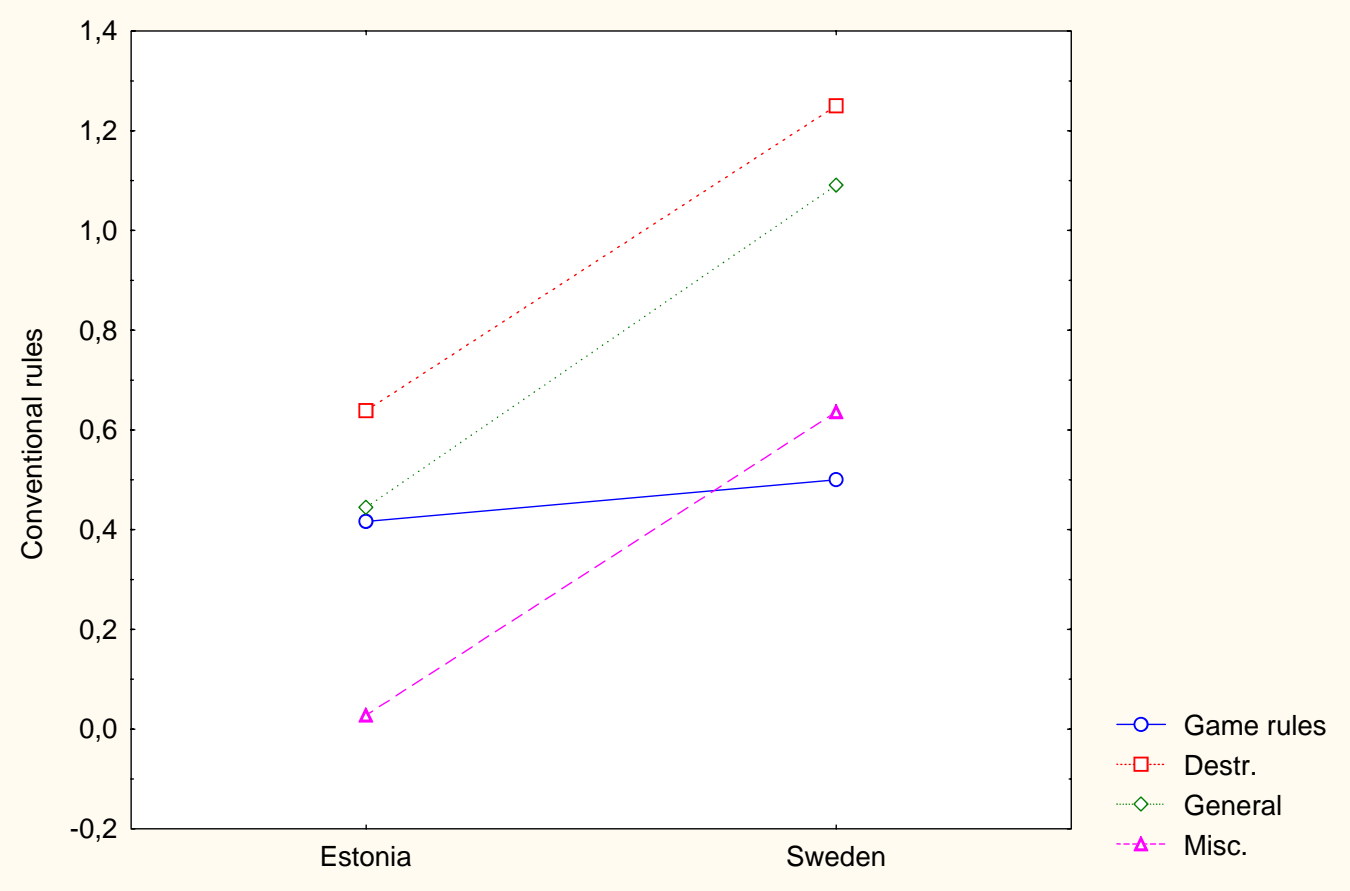

Concerning the categories General moral conventions, Destruction of property/tidiness of house and General conventional behavior, differences were did not reach statistical significance albeit the Swedish children commented on these rules more often than the Estonian children. 
Among moral rules, Estonian children mentioned positive justice the most frequently, whereas Swedish children concentrated more on rights and harm to others. Among social conventional rules, destruction/tidiness was the most important, and general convention the second important subcategory for both Estonian and Swedish children, based on how frequently children mentioned rules from these subcategories.

\section{Gender differences}

The only gender differences found concerned General moral exhortations, $F(1,78)=4.45$, $\mathrm{p}<.05$. In addition, an ANOVA for referring to Rights revealed a trend of the effect of gender, $F(1,78)=3.31, p=.07$. Both types of rules were used significantly more often by girls than by boys (see Table 4)

Table 4. Mean numbers of socio-moral utterances per gender.

\begin{tabular}{lcc}
\hline & Boys & Girls \\
\hline & & \\
Rights & 0,09 & 0,14 \\
General moral & 0,06 & 0,32 \\
\hline
\end{tabular}

\section{Outcome}

Table 5 presents the results of the outcomes. In both groups, moral comments were most often met by agreement. Social-conventional rules were mainly met by agreement in the Swedish group but by silence in the Estonian group. However, a great deal of the comments on both moral and social-conventional rules was followed by silence also by the Swedish group. Rejection was more common in the Estonian group, both following moral and social-conventional rules. Negotiation was not a frequent outcome in any of the groups.

Table 5. Mean numbers of different outcomes (and \%)

\begin{tabular}{lcl}
\hline & Estonian & Swedish \\
\hline Moral rules: & & \\
Agreement & 0.20 & 0.55 \\
Rejection & 0.10 & 0.07 \\
Negotiation & 0.07 & 0.18 \\
Silence & 0.05 & 0.41 \\
& & \\
Conventional rules: & & \\
Agreement & 0.38 & 1.73 \\
Rejection & 0.28 & 0.18 \\
Negotiation & 0.05 & 0.16 \\
Silence & 0.70 & 1.39 \\
& & \\
All rules (\% of all outcome): & \\
Agreement & $0.60(32)$ & $2.25(49)$ \\
Rejection & $0.38(21)$ & $0.25(5)$ \\
Negotiation & $0.10(5)$ & $0.34(7)$ \\
Silence & $0.78(42)$ & $1.80(38)$ \\
& & \\
\hline
\end{tabular}




\section{Discussion}

Our results revealed both differences and similarities between the two groups.

\subsection{Amount of socio-moral comments}

Following our hypothesis, we found that the Swedish group made considerably more comments on moral and social-conventional rules than the Estonian group. This was also in line with our previous research (De Geer et al. 2002), where it was shown that Swedish families were more focused on discussing socio-moral rules during dinner conversation than were Estonian families. The Swedish families had a mean number of 0.27 comments per family on socio-moral behavior, whereas the Estonian families had 0.06. In the present study the corresponding figure per dyad is 0.47 for the Swedish group and 0.18 for the Estonian group, i.e. higher values than in family interaction.

\subsection{Type of behavior commented on}

Social-conventional rules were mentioned more often than moral rules (55 vs. 18 in the Estonian data and 152 vs. 52 in the Swedish data). This was contrary to our hypothesis, which was based both on our previous findings (De Geer 2004), where children raised moral and social-conventional matters equally often. It was likewise contrary to Dunn \& Munn's claim (1987) that we can expect more conflicts concerning rights and possessions, i.e. mentioning of moral rules, in peer interaction as opposed to motherchild interaction. In our material, only Estonian children dealt a lot with positive justice, mainly with issues who gets to play with what toy and with how many toys. We can agree with Meyer (1992) that such types of disputes concern power and dominance, as illustrated in excerpt (5):

(5) "Five cars" - Estonian boys dyad playing with cars.

1 Jüri: $\quad$ mul on viis autot juba.

2 Jaan: nii palju autosid ei saa olla teises majas peab ka rohkem autosi olema kaks tükki.

3

\section{Jüri:}

5 Jaan: sul ei pea nii palju olema. nüüd ma võtsin sult ühe ära.
mhh nüüd ma andsin sulle vastu teise politseiniku.

7 Jaan: vastu.

8 Jüri: $\quad$ mul on viis autot.

9 Jaan: mul on ikka kolm.
I have five cars already. you can't have so many cars the other house too needs to have more cars two cars.

you don't have to have so many.

I don't know I have bought so many. now I took one away from you. mhh now I gave you a second policeman in return. in return. I have five cars. I still have three. 
Our results were also contrary to Haste (1987), who claimed that preschool children more often raise moral issues than social-conventional ones. One way of explaining this divergence could be that our study was made in a kindergarten environment, where issues of ownership and justice might not be as frequent as in home interaction because there are no owners of toys and when it comes to rights and responsibilities the same rules apply to everyone. When the question of justice is raised, it is often a matter of distributive justice (how to distribute goods), or as in (1) "Cutting the pizza". Anyhow, the finding of the current study that during peer talk a lot of conventional rules are used, demonstrates that peers are likely to play an important role not only in moral development, as it has been stressed by literature, but also in development of understanding of social conventional rules.

Both in the present study and in De Geer (2004) there was thus less focus on moral rules. In family dinner interaction, when commenting on the behavior on someone not present at the table, the focus of the comment was quite likely to be concerned with moral rules. Peer interaction, of course, is rather about here-and-now than on more de-contextualized topics. Social-conventional rules were most often commented on when transgressed by someone present. Moral rules appear to be more serious, and thus commenting on transgressions will be more face threatening. Socialconventional rules are more arbitrary and agreed-upon within a smaller group and might therefore need to be mentioned more often.

We found significant differences between the two groups concerning rules of rights (possession and ownership and rules of harm to others) and unkindness (teasing and hitting). In both these categories the Swedish children made more comments than the Estonian children. This confirms earlier results from the same data (De Geer et al. 2005), where we found that the same Swedish children made significantly more comments on negative fairness in game play. At the same time, the Swedish group more often than the Estonian group, offered help to their peers during play, i.e. expressed kindness. By tradition, the pedagogic ideology of schools and other institutions in Sweden has focused on children's active participation and democratic rights (Aronsson and Evaldsson 1993). Could it be the case that the Swedish children are violating rules more often than the Estonian children, thus triggering comments of socio-moral character from their peers? Are the Estonian children "behaving better" than the Swedish children, i.e. not taking the friends' things etc., at least not in front of the researchers? This is not possible to say for sure, but it also seems reasonable to believe that the Swedish children are freer, both to raise socio-moral questions and even to behave less properly in front of the camera - a freedom which may stem from their upbringing.

The Swedish children also made significantly more comments on miscellaneous social-conventional rules. Examples: Den där stolen passar bättre! [That chair is better!], Hon har fått hjärnskakning det var därför hon får sitta här inne. [She has got a brain concussion that's why she must sit here inside.] and Men jag tycker inte att du ska vara tjuv. [But I don't think you should be a thief.]. In short, the Swedish examples support the claim made by Evaldsson (1993), who studied interaction in two Swedish child-care institutions and found that social order is indeed achieved by talk.

Contrary to a previous study of Estonian children (Tulviste \& Koor 2005) boys were not found to refer more to moral rules, but girls made more reference to social conventions. A reason for this could be that in the Tulviste and Koor study was based on audio recordings, whereas in the current study children's interactions were video 
recorded. It is possible that in front of a camera, at least Estonian children violate fewer moral rules than they otherwise do.

\subsection{Outcome of socio-moral comments}

In outcomes, we found that agreement was the most common category in reply to a moral comment in both groups. Concerning social-conventional rules, agreement was still the most frequent outcome in the Swedish group, whereas silence was most frequent in the Estonian group.

Agreement was the most common outcome in the Swedish group, both in reply to moral and to social-conventional rules. Particularly after social-conventional rules the agreement also involved a "continuation" of the rule comment (42\% of all agreement to social-conventional rules and $22 \%$ of all agreement to moral rules), as in example (6), where line 4 and 5 represent “continuations”:

(6) “The mat” - Swedish girls dyad playing home.

$\begin{array}{lll}1 \text { Ebba: } & \text { mattan brukar ju faktiskt vara på golvet. } & \text { the mat usually stays on the floor. } \\ 2 & \text { varför ligger den på spisen då? } & \text { then why is it on the stove? } \\ 3 \text { Inga: } & \text { jag vet inte. } & \text { I don’t know. } \\ 4 & \text { vi kanske ska lägga ut den på golvet. } & \text { maybe we should put it on the floor. } \\ 5 & \text { vi } \text { kan ju inte äta matta till mat? } & \text { we can't eat mat for dinner, can we? }\end{array}$

The Estonian children more commonly used rejection. To overtly reject a rule is of course a quite direct way of expressing one's opinion and it confirms earlier research which has claimed Estonian groups to be more direct and controlling than Swedish groups (De Geer \& Tulviste 2002; De Geer, Tulviste \& Mizera 2005). In (7) lines 5 and 7 are examples of rejection.

(7) “Whispering” - Estonian boys dyad.

$\begin{array}{lll}\text { 1 Mihkel: } & \text { Peeter! } & \text { Peeter! } \\ 2 \text { Peeter: } & \text { noh? } & \text { well? } \\ 3 & \text { mis sa sosinal räägid? } & \text { why are you whispering? } \\ 4 & \text { sosinal kogu aeg Mihkel räägid. } & \text { you are whispering all the time, Mihkel. } \\ 5 \text { Mihkel: } & \text { ei räägi. } & \text { I am not. } \\ 6 \text { Peeter: } & \text { räägid küll ennem rääkisid. } & \text { yes you are before you were. } \\ 7 \text { Mihkel: } & \text { ei. } & \text { no. }\end{array}$

It was somewhat surprising to find that negotiation was not at all frequent in either of the groups. On one hand, children at this age are not very good in expressing and defending their point of view. On the other, this result was completely contrary to all our previous studies, where the Swedish groups, both adolescents and parents, have been found to negotiate significantly more than Estonian youths and parents. This has been the case with metapragmatic comments (De Geer et al. 2002) and regulation (De Geer \& Tulviste 2002) in family interaction, and with cooperation and competition during play (De Geer et al. 2004) and regulation (De Geer et al. 2005) in kindergarten interaction. Some of these studies are made on the same data as the present one, and 
negotiation is indeed present. However, in De Geer's (2004) study on comments on socio-moral behavior in family interaction where negotiation was the most frequent outcome, it was also found that when a comment was uttered by a child and aimed at another child's behavior agreement was most frequent $(47 \%)$, followed by silence (32\%). Negotiation was less common in these cases (16\%).

Example (8), where two Swedish boys are involved in car play, does contain negotiation. However, the negotiation is not the consequence of the moral comment, but rather the cause of it.

(8) “The thief” - Swedish boys dyad playing with cars.

\begin{tabular}{|c|c|c|}
\hline 1 Anders: & jaha då är dina vakter där då? & right, then your guards are there? \\
\hline 2 Jonas: & ja mina vakter är här på rad. & yes my guards are here in a row. \\
\hline 3 & fast jag är där. & but I am there. \\
\hline 4 & så dom behöver inte vakta. & so they don't need to guard. \\
\hline 5 Anders: & $+<x x x$ & \\
\hline 6 Jonas: & $+<$ men dom står där ute. & but they are out there. \\
\hline 7 Anders: & +> men jag är tjuv och jag ville & but I'm a thief and I wanted \\
\hline 8 & hjälpa er som inte vågar ta mej så dom & to help you who don't dare to take me \\
\hline & aj aj aj aj aj aj aj! & so they aw aw aw aw aw aw! \\
\hline 10 Jonas: & men jag vill inte att du ska vara tjuv. & but I don't want you to be a thief. \\
\hline 11 Anders: & men jag är tjuv. & but I am a thief. \\
\hline 12 & och nu skulle dom ha kul. & and now they were going to have fun. \\
\hline 13 \%соm: & Anders takes Jonas’ car. & \\
\hline 4 Anders: & den hade jag. & one. \\
\hline $\begin{array}{l}15 \text { Jonas: } \\
6 \text { Anders. }\end{array}$ & men sluta och ta mina bilar. & ing my cars. \\
\hline
\end{tabular}

Silence was the most common outcome to social-conventional rules in the Estonian group. It was also the second most frequent outcome in the Swedish group to both moral and social-conventional rules. In the present study, there were only small differences between the two groups' silence in response to a comment. This is surprising as in several of our previous studies - of both family and child data - we have found that the Estonian groups more often remain silent in return to comments (De Geer et al. 2002), and to regulation (De Geer \& Tulviste 2002; De Geer, Tulviste \& Mizera 2005). In De Geer (2004) we found silence in 22-25\% of all outcomes toward comments on socio-moral behavior in family dinnertime interaction. There were no differences between adults and children. In the present study the corresponding figure is 42\% for the Estonian group and 39\% for the Swedish group. We have previously suggested that silence following behavior regulation may indicate both protest as well as agreement (De Geer \& Tulviste 2002). We have also concluded that Swedes are more dependent on verbal acknowledgement in conversation than Estonians, who in turn have been found to be more tolerant towards silence (Kivik 1998). Therefore, it remains difficult to explain the unexpected similarity regarding silence as outcome to sociomoral rules, especially since other studies on the same data have showed a low number of "silent" outcomes in the Swedish group. One possible explanation, however, could be sought in the fact that in De Geer (2004) the percentage of silence as outcome to comments on socio-moral behavior was higher when the comment was directed to someone present at the dinner table, and lower when aimed at the behavior of someone not present (a school teacher, a friend, a colleague etc.). In the present study the absolute majority of comments are aimed at the peer. Some of them are quite face 
threatening, like "You are not fair" but others more harmless, like the mentioning of some rule for the play going on, such as "You are only allowed to drive in the street". Furthermore, silence was the second most common outcome as response to a sociomoral comment from one child to another (De Geer 2004).

\section{Summary}

The Swedish kindergarten peers in this study showed a great concern about moral and social-conventional rules during their free play conversations. They made significantly more socio-moral comments than did the Estonian children and thus confirmed the results found regarding socio-moral comments in Swedish family dinnertime interaction (De Geer 2004). Both the Estonian and the Swedish children made more comments referring to social-conventional than to moral rules.

The Swedish children made significantly more comments on rules of Rights, Harm to others and Miscellaneous conventional rules. Previous research in family dinner conversations in Estonia and Sweden has suggested a more egalitarian interaction pattern in the Swedish homes than in the Estonian homes (e.g. De Geer et al. 2002; Tulviste et al. 2002). A high amount of comments on socio-moral behavior, particularly comments on rights and harm to others, can be claimed to a further support for the democratic interaction often found in Swedish data and which is also characteristic for the pedagogic ideology of Swedish childcare and schools.

There were differences between the two groups concerning outcomes of comments on moral rules and social-conventional rules. Whereas moral rules were most likely to be met by agreement by children in both groups, the Estonian children rejected social-conventional rules more often than the Swedish children.

Cross-cultural comparisons of interaction data from disparate cultures are likely to reveal differences. The present study adds to previous research on Estonian and Swedish interaction data in home and in kindergarten settings and shows that comparing two neighboring cultures, which are in many respects similar, can be a fruitful and interesting project.

\section{List of abbreviations used in transcriptions}

+ interrupted speech

$+\quad$ interrupting speech

\# $\quad$ short pause

\#10 pause of 10 seconds

$\mathrm{xxx}$ unintelligible speech

bold bold typescripts are used to highlight the category discussed in the text 


\section{References}

Aronsson, Karin, \& Ann-Carita Evaldsson (1993) Pedagogic discourse and interaction orders: Sharing time and control. In: N. Coupland \& J.F. Nussbaum (eds.), Discourse and lifespan identity. London: Sage Publications, pp. 103-131.

Aukrust, Vibeke Grøver, \& Catherine Snow (1998) Narratives and explanations during mealtime conversations in Norway and the U.S. Language in Society 27: 221-246.

Becker, Judith (1990) Processes in the acquisition of pragmatic competence. In: Gina Conti-Ramsden \& Catherine Snow (eds.), Children’s Language 7. Hillsdale N.J.: Lawrence Erlbaum, pp. 7-24.

Blum-Kulka, Shoshana (1990) You don't touch lettuce with your fingers: Parental politeness in family discourse. Journal of Pragmatics 14: 259-288.

Blum-Kulka, Shoshana (1997) Dinner talk. Cultural patterns of sociability and socialization in family discourse. Mahwah N.J.: Lawrence Erlbaum.

Blum-Kulka, Shoshana, \& Hadass Sheffer (1993) The metapragmatic discourse of American-Israeli families at dinner. In Gabriele Kasper \& Shoshana Blum-Kulka (eds.), Interlanguage Pragmatics. Oxford: Oxford University Press, pp. 196-223.

Daun, Åke (1991) Individualism and collectivity among Swedes. Ethnos 56.3-4: 165-172.

De Geer, Boel (2004) ”Don’t say it’s disgusting!” Comments on socio-moral behavior in Swedish families. Journal of Pragmatics 36.9: 1705-1725.

De Geer, Boel, \& Tiia Tulviste (2002) Behaviour regulation in the family context in Estonia and Sweden. Pragmatics 12.3: 329-346.

De Geer, Boel, Tiia Tulviste, Luule Mizera, \& Marja-Terttu Tryggvason (2002) Socialization in communication: Pragmatic socialization during dinnertime in Estonian, Finnish and Swedish families. Journal of Pragmatics 34: 1757-1786.

De Geer, Boel, Tiia Tulviste, \& Luule Mizera (2005) Regulation of behavior and attention in peer interaction in Estonia, Finland, and Sweden. Pragmatics 15.1: 1-24.

Dunn, Judy, \& Penny Munn (1987) The development of justification in disputes with mother and sibling. Developmental Psychology 23: 791-798.

Eriksen, Thomas (1993) Being Norwegian in a shrinking world. In A. Kiel (ed.), Continuity and change: Aspects of contemporary Norway. Oslo: Scandinavian University Press, pp. 11-37.

Evaldsson, Ann-Carita (1993) Play, disputes and social order. Everyday life in two Swedish after-school centers. Linköping Studies of Arts and Science 93. Linköping: Linköping University.

Feilberg, Julie (1991) To må man være. Mor-barn dialoger i et utviklingsperspektiv. University of Trondheim.

Haste, Helen (1987) Growing into rules. In J. Bruner \& H. Haste (eds.), Making sense: The child's construction of the world. London: Methuen, pp. 195.

Junefelt, Karin, \& Tiia Tulviste (1998) American, Estonian and Swedish mothers' regulation of their children's discourse construction. In Maria Lyra \& Jaan Valsiner (eds.), Construction of Psychological Processes in Interpersonal Communication. Stanford, Conn.: Ablex Publishing Corporation, pp. 137-154.

Kivik, Piibi-Kai (1998) What silence says: Communicative style and identity. Trames 2.52/47: 66-90. 
Kuczynski, Leon, \& Grazyna Kochanska (1990) Development of children’s noncompliance strategies from toddlerhood to age 5. Developmental Psychology 26.3: 398-408.

Kuczynski, Leon, Grazyna Kochanska, Maruab Radke-Yarrow, \& Ona Girnius-Brown (1987) A developmental interpretation of young children's noncompliance. Developmental Psychology 23.6: 799806.

Löfgren, Orvar (1993) The cultural grammar of nation-building: The nationalization of nationalism. In P. J. Antonnen \& R. Kvideland (eds.), Nordic frontiers: Recent issues in the study of modern traditional culture in the Nordic countries. Turku: Nordic Institute of Folklore, pp. 217-238.

MacWhinney, Brian (1991) The CHILDES project. Tools for analyzing talk. Hillsdale, N.J.: Lawrence Erlbaum.

Meyer, Jasna (1992) The collaborative development of power in children's arguments. Argumentation and Advocacy. 29: 77-88.

Miller, Peggy, \& Jacqueline Goodnow (1995) Cultural practices: Toward an integration of culture and development. In J. Goodnow, P. Miller \& F. Kessel (eds.), Cultural practices as contexts for development. San Francisco: Jossey-Bass, pp. 5-16.

Ochs, Elinor, \& Carolyn Taylor (1992) Family narrative as political activity. Discourse and Society 3.3: 301-340.

Ochs, Elinor (1996) Linguistic resources for socializing humanity. In John Gumperz \& Stephen Levinson (eds.), Rethinking linguistic relativity. Cambridge: Cambridge University Press, pp. 407-437.

Piotrowski, Caroline (1997) Rules of everyday life: The development of social rules in mother-child and sibling relationships. International Journal of Behavioural Development 21.3: 571-598.

Rogoff, Barbara (1990) Apprenticeship in thinking: Cognitive development in social context. New York: Oxford. University Press.

Skogar, Björn (2000) I stormens öga - några inledande teoretiska vägval i religionsdidaktiken. In E. Almén, R. Furenhed, S. Hartman \& B. Skogar (eds.), Livstolkning och värdegrund. Att undervisa om religion, livsfrågor och etik. Linköpings universitet: Skapande vetande 37: 102-116.

Smetana, Judith (1989) Toddlers' social interactions in the context of moral and conventional transgressions in the home. Developmental Psychology 25: 499-508.

Smetana, Judith (1993) Understanding of social rules. In M. Bennett (ed.), The child as psychologis: An introduction to the development of social cognition. New York: Harvester, pp. 111-141.

Smetana, Judith, \& Judith Braeges (1990) The development of todders' moral and conventional judgments. Merrill-Palmer Quarterly 36: 329-346.

Smetana, Judith, Naomi Schlagman, \& Patricia Walsh Adams (1993) Preschool children's judgments about hypothetical and actual transgressions. Child Development 64: 202-214.

Smetana, Judith, Hugh Crean, \& Nicole Campione-Barre (2005) Adolescents’ and parents’ conceptions of parental authority. New Directions for Child and Adolescent Development 108: 31-46.

Tannen, Deborah (1981) Indirectness in discourse: Ethnicity as conversational style. Discourse Processes 36.3: 221-238.

Tisak, Marie S., \& Elliot Turiel (1984) Children’s conceptions of moral and prudential rules. Child Development 55: 1030-1039. 


\section{Boel De Geer and Tiia Tulviste}

Tulviste, Tiia, \& Marju Koor (2005) "Hands off the car, it’s mine!" and "The teacher will be angry if we don't play nicely": Gender-related preferences in the use of moral rules and social conventions in preschoolers' dyadic play. Sex Roles: A Journal of Research 53: 57-66.

Tulviste, Tiia, Luule Mizera, Boel De Geer, \& Marja-Terttu Tryggvason (2002) Verbal comments as tools of family socialization: A comparison of Estonian, Swedish and Finnish mealtime interaction. Language in Society 31: 655-678.

Turiel, Elliot (1983) The development of social knowledge. Cambridge: Cambridge University Press. 